\title{
Traditional practices of utilization and conservation of non-wood forest products by Adi tribes of Arunachal Pradesh
}

\author{
Naresh Kumar*, Sanjeev Kumar, Bikram Singh, B. P. Mishra, Barun Singh and Vikas \\ Singh
}

College of Horticulture and Forestry, Central Agricultural University, Pasighat, East Siang 791102 (Arunachal

Pradesh), INDIA

*Corresponding author. E-mail: nareshbhardwaj50@gmail.com

Received: October 10, 2014; Revised received: March 5, 2015; Accepted: March 15, 2015

\begin{abstract}
The survey was carried out during 2009-11 to collect the information of Non-Wood Forest Products (NWFPs) utilized by the Adi tribes of East Siang District of Arunachal Pradesh. It was observeds that Adi tribes used to collect different NWFPs such as wild fruits (Artocarpus heterophyllum Lam., Castanopsis indica (Roxb. ex Lindl.) A. DC., Canarium strictum Roxb. etc.), vegetables (Bauhinia variegata L., Clerodendrum colebrookianum Walp., Diplazium esculentum (Retz.) Sw., Moringa oleifera Lam. etc.), spices (Cinnamomum tamala Nees \& Eber., Cinnamomum zeylanicum Blume. and Piper longum L.), fibres (Calamus flagellum Griff. ex Mart., Dendrocalamus hemiltonii Nees et Arn. ex Munro, Pandanus nepaulensis H. St. John and Sterculia villosa Roxb.), floss (Bombax ceiba L.,), broom grass (Thysanolaena maxima (Roxb.) Ktze.), thatching material (Livistona jenkinsiana Griff.), various bamboo and cane species, and other miscellaneous products from the forests and community lands. NWFPs played a significant role in supporting the livelihood of Adi tribes as it has been observed that $32.50 \%, 56.67 \%$ and $10.83 \%$ people were earning < Rs. 3000 , Rs. $3000-6000$ and > Rs. 6000 , respectively from the sale of different NWFPs. Majority of respondents $(80.83 \%)$ were having the opinion that the availability of different NWFPs has declined considerably and maximum ( $85 \%$ ) respondents advocated that the availability of these products would further decrease in future also. Further, Adi tribal community is playing an important role in conservation of different NWFPs yielding species by domesticating them in their home gardens.
\end{abstract}

Keywords: Adi tribes, Conservation, Domestication, Non-wood forest products

\section{INTRODUCTION}

Non-wood forest products (NWFPs) are important in the daily life and for the well being of the rural population. In addition to local consumption, NWFPs are also important traded commodities on regional, national as well as international markets. Traded NWFPs contribute to the fulfillment of daily needs and provide employment as well as income. Ethnic tribes derive a large proportion of their annual per capita income from these products (Narendran et al., 2001). There is a growing awareness of the importance of NWFPs and this awareness is not only for the role they play in the subsistence economy, but also for their potential and real contribution to the economies of many developing countries (FAO,1998). Non-wood forest products once neglected as minor forest produce, now have gained significant importance due to its income and employment potential (Muraleedharan et al., 2004). Evaluation and monitoring of the resources providing NWFPs are important to estimate the actual and potential socio-economic and ecological value of these products. The first step in this process is the identification of the resources providing NWFPs.
Harvesting of NWFPs might cause degradation of the habitat if the exploitation is carried out in an unsustainable way. On the other hand, habitat degradation might also have a negative influence on the availability of NWFPs. Some of the plant species which were reported to occur commonly or abundantly about half a century ago have at present became rare or very rare due to over exploitation/ habitat loss and have fallen in the category of endangered species. A large number of highly useful herbaceous plants have little future, unless immediate steps are not taken to arrest the causes leading to ecological and biological impoverishment (Pattanaik and Reddy, 2012).

The north-east India is a part of both Himalaya as well as Indo-Burma biodiversity hotspots in the world. It has the richest reservoir of plant diversity in India and is one of the 'biodiversity hotspots' of the world supporting about $50 \%$ of India's biodiversity (Mao and Hynniewta, 2000). Northeastern region including Arunachal Pradesh occupy $7.7 \%$ of total geographical area of country and harbours $50 \%$ of Indian flora $(8,000$ species $)$ of which about $4 \%$ is endemic $(2,526$ species) (Rao and Hajra, 1980; Nayar, 1996). The 
distinct tribes in the region have rich indigenous knowledge system on the use of components of biodiversity for their daily sustenance like food, fodder, shelter and healthcare. The knowledge and utilization of local plants depends on the ethnic group they belong to and also their remoteness from the modern world. Forests in general are regarded with reverence and certain states have a number of sacred grooves, they considered abodes of their gods, where cutting of trees are prohibited (Tiwari et al., 1999; Barik et al., 2006; Samati and Gogoi, 2007). Arunachal Pradesh is situated on the Great Eastern Himalayan Mountain range and recognized as one of the Mega Biodiversity hot spot of the world (Myers et $a l ., 2001)$. The state has a great ethno-cultural diversity with 28 major and 110 sub-tribes. People of Arunachal Pradesh have their own culture, tradition and medicinal system of treatment and knowledge acquired through close observation of nature. They are store house of indigenous knowledge (Srivastava and Adi Community, 2009). Its ethnic people living in the remote forest areas still depend to a greater extent on the forest ecosystems for their livelihood. Non-timber forest products play a significant role for sustaining the livelihood of tribal and even non-tribal communities in North East India (Dattagupta and Gupta, 2014). Adi is second largest tribal community of state of Arunachal Pradesh and inhabits the Siang belt (Upper, West and East Siang), Upper Subansiri and Dibang Valley. East Siang District is mostly inhabited by the Adi tribe which comprises of a large number of tribal groups (Minyongs, Padams, Shimongs, Milangs, Pasis, Karkos, Ashings, Pangis, Tangams, Boris etc.). They traditionally practice shifting and terrace cultivation in hills and wet rice cultivation in valleys (Yumnam and Tripathi, 2013). Like many other tribal groups, the Adi tribes also largely depend on the bio-resources for their livelihood. Their core diet includes rice, millets and a wide variety of local semi-domesticated and wild plants (Yumnam et al., 2011). Proteins requirements are supplemented with animal meat, bush meat including birds and fishes (Yumnam and Tripathi, 2013).

In order to reduce the pressure on NWFPs resources, and to utilize the full potential of NWFPs to provide employment and increase the income levels of tribal people, more attention should be given for domestication of potential plants and promoting their cultivation by individuals, communities, Self Help Groups (SHGs) etc. The first step in this process is the identification and documentation of the resources providing NWFPs. This information can be utilized for the conservation of these resources and their cultivation at a larger scale for improved livelihood opportunities. Keeping in view the importance of non-wood forest products, the present study was carried out among the Adi tribes of East Siang District of Arunachal Pradesh.

\section{MATERIALS AND METHODS}

Multistage sampling technique was applied to select the locale and target group of the study. Pasighat Block of East Siang district was selected purposively because population-wise it is the largest Block and the majority of the tribal people of this area are involved in collection and utilization of non-wood forest products (Singh et al., 2007). To get the best representation of area, 12 villages were selected randomly from Pasighat Block. Thereafter, the list of households involved in Non-Wood Forest Products collection and utilization related activities were prepared with the help of key informants and village head (locally known as Gaon Burha). The focused group discussion was organized in each selected village on collection, utilization and conservation pattern of NWFPs. Ten households from each village (Total $12 \times 10=120$ no.) were taken randomly for the collection of data. The data was collected through extensive household survey and by adopting PRA tools and techniques (Mukherjee, 2003). Semi--structured schedule containing open-ended questions was used to interview informants. The focused group discussions were organized to cross-verify the recorded information, social validation and to improve reliability of data-set. Ranking matrix was done with the scoring of a range of criteria against a range of comparable NWFP items. The scoring takes place in a grid like set-up with items in one side and preference on other.

\section{RESULTS AND DISCUSSION}

The present study revealed that the 'Adi' tribe community collects different Non-Wood Forest Products (NWFPs) from the forests. The collection of these products is mainly done by the women who are accompanied by their children. Hunting is a part of their culture and also forms a part of their economy. Generally, it is carried out by the males of family and in specific season/period. The different NWFPs observed in the study area have been categorized into different categories viz.: i) Fruits from forests ,ii) Vegetables from forests, iii) Spices from forests, iv) Fibres, flosses, broom and thatching material from forestsv) Others NWFPs .

It has been observed that 12 species of wild fruits belonging to 12 families, 12 species of wild vegetables belonging to 10 families, 3 spices yielding species belonging to 2 families, 4 fibres yielding plant species belonging to 4 families, 1 floss yielding tree belonging to Bombcaceae family, 1 broom grass belonging to Poaceae family, 1 thatching material yielding species belonging to Arecaceae family are collected and utilized by the Adi tribes. In addition to this, they are also getting different animal products (e.g. meat, skin, feather, teeth, honey etc.) and wild mushroom, resin etc. These products are used for self consumption as well as for selling in the local markets at varying levels of quantities. The different NWFPs collected are discussed as: 
1. Fruits from the forests .

\begin{tabular}{|c|c|c|c|}
\hline S.N. & $\begin{array}{l}\text { Scientific name and } \\
\text { family }\end{array}$ & $\begin{array}{c}\text { Common name/ } \\
\text { Local name }\end{array}$ & Uses \\
\hline 1 & $\begin{array}{l}\text { Artocarpus heterophyl- } \\
\text { lus Lam. (Moraceae) }\end{array}$ & $\begin{array}{c}\text { Jack fruit, } \\
\text { Katahal, Belang }\end{array}$ & $\begin{array}{l}\text { Un-ripened fruit is used for pickle making and also } \\
\text { cooked as vegetable, whereas after ripening it gives sweet } \\
\text { taste. After eating the sweet fleshy part, the seeds are also } \\
\text { cooked or roasted for consumption. The fruits are also fed } \\
\text { to pigs. The un-ripened as well as ripened fruits are also } \\
\text { sold in the local market. }\end{array}$ \\
\hline 2 & $\begin{array}{l}\text { Castanopsis indica } \\
\text { (Roxb. ex Lindl.) A. } \\
\text { DC. (Fagaceae) }\end{array}$ & $\begin{array}{l}\text { Katus, Sirang, } \\
\text { Anke, }\end{array}$ & $\begin{array}{l}\text { The nuts after removing the thorny covering are eaten } \\
\text { directly as raw or after roasting. There is a good demand } \\
\text { of these nuts and also being sold in the local market. }\end{array}$ \\
\hline 3 & $\begin{array}{l}\text { Canarium strictum } \\
\text { Roxb. } \\
\text { (Burseraceae) }\end{array}$ & Silum, Dhuna, & $\begin{array}{l}\text { Fruit is edible. Its resin is burnt traditionally to produce } \\
\text { smoke which acts as a mosquito repellent. Fruits as well } \\
\text { as resins are being sold in the local market. }\end{array}$ \\
\hline 4 & $\begin{array}{l}\text { Dillenia indica L. } \\
\text { (Dilleniaceae) }\end{array}$ & $\begin{array}{l}\text { Outenga, } \\
\text { Chompa, Sompa, }\end{array}$ & $\begin{array}{l}\text { The fleshy calyx has an agreeable acid taste and is eaten } \\
\text { raw or cooked. It is also used to make pickle. It is also } \\
\text { sold in the local market. Fruit is having laxative property } \\
\text { and is used for abdominal disorder. }\end{array}$ \\
\hline 5 & $\begin{array}{l}\text { Eleocarpus floribundus } \\
\text { Vahl. (Elaeocarpaceae) }\end{array}$ & Jalpai & Fruit is edible and also sold in the market. \\
\hline 6 & $\begin{array}{l}\text { Emblica officinalis } \\
\text { Gaertn. } \\
\text { (Euphorbiaceae) }\end{array}$ & $\begin{array}{l}\text { Aonla, Amloki, } \\
\text { amla }\end{array}$ & $\begin{array}{l}\text { Fruit is edible. It is also used in pickle, chutney making. It } \\
\text { is also having medicinal value. There is good demand of } \\
\text { this fruit in local market. }\end{array}$ \\
\hline 7 & $\begin{array}{l}\text { Nephelium lappaceum } \\
\text { L. (Sapindaceae) }\end{array}$ & Rambutan, Tadar & $\begin{array}{l}\text { The fruit resembles to the litchi fruit. The fleshy part of } \\
\text { the fruit is eaten after removing the outer layer. It is also } \\
\text { sold in the local market. }\end{array}$ \\
\hline 8 & $\begin{array}{l}\text { Phoebe cooperiana U.N } \\
\text { Kanjilal ex A. Das } \\
\text { (Lauraceae) }\end{array}$ & Tapil, Mekahi & $\begin{array}{l}\text { Un-ripened fruits are eaten. The fruits are eaten raw with } \\
\text { meal or eaten after making chutney. The fruits are also } \\
\text { being sold in the market. }\end{array}$ \\
\hline 9 & $\begin{array}{ll}\text { Spondias pinnata } & \text { P.C. } \\
\text { Kanz. and } & \text { Das } \\
\text { (Anacardiaceae) } & \end{array}$ & $\begin{array}{l}\text { Amara, Golden } \\
\text { apple, Dorge }\end{array}$ & Fruit is edible and mostly liked by the children. \\
\hline 10 & $\begin{array}{l}\text { Syzygium cumini (L.) } \\
\text { Skeels (Mytraceae) }\end{array}$ & $\begin{array}{l}\text { Jamun, Singkeng } \\
\text { Aye }\end{array}$ & $\begin{array}{l}\text { Ripen fruits are self consumed as well as sold in the local } \\
\text { market. }\end{array}$ \\
\hline 11 & $\begin{array}{l}\text { Terminalia chebula } \\
\text { Retz. (Combretaceae) }\end{array}$ & Harra, Hilika & $\begin{array}{l}\text { Fruits having medicinal properties are eaten and sold in } \\
\text { the local market. Sometimes it is also sold after drying. }\end{array}$ \\
\hline 12 & $\begin{array}{l}\text { Zizyphus mauritiana } \\
\text { Lamk. (Rhamnaceae) }\end{array}$ & Ber, Bogori & Fruits are eaten and sold in the local market. \\
\hline
\end{tabular}

2. Vegetables from the forests.

\begin{tabular}{lll}
\hline S.N. & $\begin{array}{l}\text { Scientific name and } \\
\text { family }\end{array}$ \\
1 & $\begin{array}{l}\text { Bauhinia variegata } \mathrm{L} . \\
\text { (Caesalpiniaceae) }\end{array}$ \\
2 & $\begin{array}{l}\text { Clerodendrum cole- } \\
\text { brookianum } \quad \text { Walp. } \\
\text { (Verbenaceae) }\end{array}$
\end{tabular}

3 Dendrocalamus hamiltonii Nees et Arn. ex Munro,

D. asper (Schult.f.)

Backer ex Heyne, Bambusa tulda Roxb. etc. (Poaceae)

\section{Common name/ Uses}

Local name

Kachnar, ogok

Ongin

Young leaves and flower buds are used as vegetable. Flower buds are also sold in the local market.

Tender leaves are used as vegetables and also sold in the local market. It Boiled leaves are taken against high blood pressure (Srivastava and Nyshi Community, 2010) and diabetes. Leaf juice or decoction is used for curing stomach ailments.

Bamboo (Bamboo The newly emerged shoots are harvested. People used to shoot), Dibang, consume bamboo shoots as vegetables and make pickle. Iiting, Ikung It is also consumed after fermentation and there is a good demand of fermented bamboo in the local market. 


\begin{tabular}{|c|c|c|c|}
\hline 4 & $\begin{array}{lr}\text { Diplazium } & \text { esculentum } \\
\text { (Retz.) } & \mathrm{Sw} . \\
\text { (Athyriaceae) }\end{array}$ & $\begin{array}{l}\text { Dhekia, Takang, } \\
\text { Fern }\end{array}$ & $\begin{array}{l}\text { It is a fern being used as vegetable (Srivastava and Nyshi } \\
\text { Community, 2010) and also sold in the local market. }\end{array}$ \\
\hline 5 & $\begin{array}{l}\text { Moringa oleifera Lam. } \\
\text { (Moringaceae) }\end{array}$ & $\begin{array}{l}\text { Drumstick tree, } \\
\text { Sajana }\end{array}$ & $\begin{array}{l}\text { Green fruits/pods and tender leaves are used as vegetable. } \\
\text { Generally this tree is occurring near habitation. Its pods } \\
\text { are having good demand in the local market }\end{array}$ \\
\hline 6 & $\begin{array}{l}\text { Mussenda roxburghii } \\
\text { Hook.f. (Rubiaceae) }\end{array}$ & Akshap & $\begin{array}{l}\text { Leaves are used as vegetable and also sold in the local } \\
\text { market. }\end{array}$ \\
\hline 7 & $\begin{array}{l}\text { Pouzolzia bennettiana } \\
\text { Wight. (Urticaceae) }\end{array}$ & Oyik & $\begin{array}{l}\text { Leaves and tender shoots are used as vegetables and also } \\
\text { sold in the local market. }\end{array}$ \\
\hline 8 & $\begin{array}{l}\text { Solanum indicum L. } \\
\text { (Solanaceae) }\end{array}$ & Bangko & $\begin{array}{l}\text { Leaves are consumed as vegetable and considered good } \\
\text { for stomach ailments. They are also sold in the local mar- } \\
\text { ket. }\end{array}$ \\
\hline 9 & $\begin{array}{l}\text { Solanum khasianum } \\
\text { Clarke (Solanaceae) }\end{array}$ & Kopir & $\begin{array}{l}\text { Fruits are consumed as vegetable and also sold in the } \\
\text { local market. }\end{array}$ \\
\hline 10 & $\begin{array}{l}\text { Solanum torvum Sw. } \\
\text { (Solanaceae) }\end{array}$ & Kopi & $\begin{array}{l}\text { Fruits are consumed as vegetable (Srivastava and Nyshi } \\
\text { Community, 2010) and also sold in the local market. }\end{array}$ \\
\hline 11 & $\begin{array}{l}\text { Spilanthes acmella } \\
\text { Murr. (Compositae) }\end{array}$ & Marshang & $\begin{array}{l}\text { It is cooked with other leafy vegetables and consumed, } \\
\text { although it is not consumed alone. They are also sold in } \\
\text { the local market. }\end{array}$ \\
\hline 12 & $\begin{array}{l}\text { Xanthoxylum rhetsa } \\
\text { (Roxb.) DC. (Rutaceae) }\end{array}$ & Onger & $\begin{array}{l}\text { Tender leaves and shoots are used as vegetables and sold } \\
\text { in market. Fruit is used as flavorings agent. }\end{array}$ \\
\hline
\end{tabular}

\section{Spices from forests.}

\begin{tabular}{|c|c|c|c|}
\hline S.N. & $\begin{array}{l}\text { Scientific name and } \\
\text { family }\end{array}$ & $\begin{array}{l}\text { Common name / } \\
\text { Local name }\end{array}$ & Uses \\
\hline 1 & $\begin{array}{l}\text { Cinnamomum tamala } \\
\text { Nees and } \text { Eber. } \\
\text { (Lauraceae) }\end{array}$ & Tejpatta & $\begin{array}{l}\text { Its leaves are used to give fragrance to cooked meat, } \\
\text { vegetables etc. Tejpatta is also liked by the non-tribal } \\
\text { people and there is good demand of the same in the local } \\
\text { market. }\end{array}$ \\
\hline 2 & $\begin{array}{l}\text { Cinnamomum zeylani- } \\
\text { cum Blume. (Lauraceae) }\end{array}$ & $\begin{array}{l}\text { Dalchini, } \\
\text { siripori }\end{array}$ & $\begin{array}{l}\text { Its bark is being used to impart flavour to cooked vegeta- } \\
\text { bles, meat etc. There is a good demand of Dalchini in the } \\
\text { local and nearby markets. }\end{array}$ \\
\hline 3 & $\begin{array}{l}\text { Piper longum } \\
\text { (Piperaceae) }\end{array}$ & Pipali & $\begin{array}{l}\text { It is not used very commonly by local people; some times } \\
\text { its fruit are used to give fragrance especially to meat. The } \\
\text { fruits are being collected by the local people and supplied } \\
\text { to Guwahati/Kolkata/Delhi market. }\end{array}$ \\
\hline
\end{tabular}

\section{Fibres, flosses, broom and thatching material from the forests.}

\begin{tabular}{|c|c|c|c|}
\hline S.N. & Scientific name & $\begin{array}{l}\text { Common } \\
\text { name/ Local } \\
\text { name }\end{array}$ & Uses \\
\hline \multicolumn{4}{|c|}{ Fibres } \\
\hline 1. & $\begin{array}{l}\text { Calamus flagellum Griff. ex } \\
\text { Mart., C. tenuis Roxb., C. } \\
\text { acanthospathus Griff. etc. } \\
\text { (Arecaceae) }\end{array}$ & $\begin{array}{l}\text { Cane/Rattan, } \\
\text { Takat, Jeying, } \\
\text { Ramang, }\end{array}$ & $\begin{array}{l}\text { The canes are being used for making furniture items, } \\
\text { hats, baskets and other domestic useable and decora- } \\
\text { tive items. They are also being used as substitute for } \\
\text { ropes and cables and mainly being used for making } \\
\text { the traditional house (Tokopatta House) for binding } \\
\text { the bamboo and Tokopatta. }\end{array}$ \\
\hline 2. & $\begin{array}{l}\text { D. hemiltonii Nees et Arn. ex } \\
\text { Munro, Bambusa } \\
\text { sp. and }\end{array}$ & Bamboo & $\begin{array}{l}\text { The stem of bamboo is sliced to make traditional cord } \\
\text { which is used for fastening purposes. }\end{array}$ \\
\hline
\end{tabular}
other species of bamboo. (Poaceae) 
3. Pandanus nepaulensis H. St. Tako John (Pandanaceae)

4. Sterculia villosa
(Sterculiaceae)

Flosses

Bombax ceiba L.(Bombcaceae)

Roxb.

Udal (Elephant rope tree)

Semul, Gitmur (Adi)

\section{Broom}

Thysanolaena maxima (Roxb.) Ktze. Broom grass (Poaceae)

\section{Thatching material}

Livistona jenkinsiana Griff. Tokopatta (Arecaceae)
The leaves of this plant are used for mat making, cordage, fishing nets etc. The products are sold in the local market.

Bark fibre is used to make traditional ropes and bags.

\begin{tabular}{ll} 
Adi & les \\
\hline
\end{tabular}

\section{Other NWFPs}

Wild Mushroom: Different types of wild mushrooms are collected by the local people from the forests for their self consumption as well as for sale.

ii) Resin of Canarium strictum Roxb. (Dhuna): This resin is having mosquito repellent property and also being used in different ritual ceremonies by the local people. Its usage among tribal and folk people for medicinal purposes in different parts of India has been explored through ethnobotanical studies (Desha et al., 2012). Traditional healers were also using this resin for curing some ailments. Local people were collecting this resin for their self use as well as for sale purpose

Pods of Gymnocladus burmanicus C.E. Parkinson (Shikakai or Dekang): These pods are crushed and used as substitute of soap and shampoo (Kumar et al., 2011).

Income from Non-Wood Forest Products (NWFPs): The different NWFPs collected are also sold in the local market in addition to their self consumption by Adi tribes. Generally, the aged ladies are mostly engaged in selling of these products in the local market. The respondents have been categorized into three categories according to their monthly income generated from selling of NWFPs (Table 1). It has been observed that the 56.67 per cent respondents were earning Rs.3000 - 6000 per month from NWFPs related trade.

There is a good demand of bamboo, tokopatta and rat$\tan /$ cane as well as their derived products in the local markets. These products are either sold at farm gate or in the local market and thereby, support the livelihood of many families among the Adi community. The other important NWFPs sold in the local market and which also support the livelihood of Adi community are katahal/belang (A. heterophyllus Lam.), onger ( $X$. rhetsa (Roxb.) DC), ongin (C. colebrookianum Walp.), tapil/mekahi (P. cooperiana U.N Kanjilal ex A. Das), silum/ dhuna (C. strictum Roxb.), hilika (T. chebula
Its flower yield floss which is used for making of pillow, cushion etc. There is a good demand of this floss in the local market.

Inflorescence is used for making broom. The inflorescence is first collected and spread in the sun for few weeks, thereafter, bind in bundle and sold in market.

Its foliage is used as thatching material for making traditional house. It is a source of livelihood for many Adi families. Its seeds are also used in traditional pickles.

Retz.) and amloki/aonla (E. officinalis Gaertn.) etc. Present status and future availability perception about NWFPs: It has been observed during PRA exercise that the availability of NWFPs is decreasing day by day due to increase in population and thereby more pressure on the existing resources. Moreover, earlier such products were preferred by the local tribal communities only, but now these are also being liked (e.g. onger twigs as leafy vegetable) by the non-tribal people residing in the nearby localities. Hence, there is a good demand of such non-wood forest products in the local market, but sometimes it is not feasible to fulfill the market demand. The wild fruits like Tapil, Hilika, Jalpai, Aonla, Jamun etc. are also being collected from the forests and having good demand in the local market, but there is no artificial plantation of such species, thereby, there availability will also decrease in the future as trees becoming older and giving lesser yield. Similarly, cane is one of the highly demanded NWFPs products and extracted with higher pace, thereby its availability may also decrease in the future. From these observations, it is apparent that to make the sustainable supply of NWFPs to the present population, as well as for future also, there is a great need of conservation, domestication and protection of such products providing species.

It is revealed from table 2 that 80.83 per cent of the respondents were having the opinion that the availability of different NWFPs had decreased in comparison to few years back, whereas 19.16 per cent advocated that the availability was same. Almost same trend was observed regarding future availability of these products. The maximum respondents $(85 \%)$ believed that the availability of NWFPs would decrease in future.

Conservation of non-wood forest products (NWFPs) and their ranking for domestication: Home garden is very common practice in north-eastern 
Table 1. Distribution of respondents according to their income (Rs.) from NWFPs $(\mathrm{N}=120)$.

\begin{tabular}{llcc}
\hline S. N. & Category & Frequency & Percentage \\
\hline 1 & $<$ Rs. 3000 per month & 39 & 32.50 \\
2 & Rs. 3000 - 6000 per month & 68 & 56.67 \\
3 & $>$ Rs. 6000 per month & 13 & 10.83 \\
\hline
\end{tabular}

Table 2. Present status of NWFPs and perception about their future availability.

\begin{tabular}{|c|c|c|c|}
\hline \multirow{2}{*}{$\begin{array}{l}\text { Status / Perception about } \\
\text { NWFPs }\end{array}$} & \multicolumn{3}{|c|}{ Response of forest dwellers/respondents } \\
\hline & Increased & Decrease & Same \\
\hline $\begin{array}{l}\text { Status of NWFPs in com- } \\
\text { parison to last five years }\end{array}$ & $0.00(0 \%)$ & $97(80.83)$ & $23(19.16 \%)$ \\
\hline $\begin{array}{l}\text { Perception about the future } \\
\text { availability of NWFPs }\end{array}$ & $0.00(0 \%)$ & $102(85.00 \%)$ & $18(15.00 \%)$ \\
\hline
\end{tabular}

Table 3. Ranking matrix on preferred species for domestication.

\begin{tabular}{llc}
\hline S. N. & Name & Rank \\
\hline 1. & $\begin{array}{l}\text { Bamboo (D. hemiltonii Nees et Arn. ex Munro, D. asper (Schult.f.) Backer ex Heyne, } \\
\text { Bambusa sp. and other species of bamboo ) }\end{array}$ & I \\
2. & Tokopatta (L. jenkinsiana Griff.) & II \\
3. & $\begin{array}{l}\text { Rattan/cane, jeying, takat, ramang, rattan (C. flagellum Griff. ex Mart., C. tenuis Roxb., C. } \\
\text { acanthospathus Griff. etc.) }\end{array}$ & III \\
4. & Katahal, belang (A. heterophyllus Lam.) & IV \\
5. & Onger (X. rhetsa (Roxb.) DC) & V \\
6. & Ongin (C. colebrookianum Walp.) & VI \\
7. & Tapil, mekahi (P. cooperiana U.N Kanjilal ex A. Das) & VII \\
8. & Silum, dhuna (C. strictum Roxb.) & VIII \\
9. & Hilika (T. chebula Retz.) & IX \\
10. & Amloki, amla (E. officinalis Gaertn.) & X \\
\hline
\end{tabular}

region especially in the rural areas. The people grow as well as maintain different plant species in their gardens. The traditional home gardens have been maintained as a part of rural survival over generations, with a complex vegetational structure harbouring diverse types of local plant species with multiple functions (Tangjang and Arunachalam, 2009). It has been observed that although the most of the NWFPs were being collected from the forests, but people were also protecting some of the plants providing NWFPs in their home garden by fencing. This practice ensures the regular supply as well as minimizes the pressure on the forests; thereby eliminate the danger of becoming such species threatened/endangered in the natural habitat. Moreover, home gardens contribute to ex situ conservation of local plant diversity and can also serve as gene pools of the eroding indigenous plant species (Das and Das, 2005). The number as well as composition of the home gardens vary with person to person, but almost every tribal family had retained the home garden. The most common plant species in the home gardens were bamboo, tokopatta, melia, kachnar, aonla, jack fruit (katahal), rattan/Cane, tamarind, banana, tejpatta, bangko, kopi, fern etc. Conservation of tokopatta in Jhum lands is a very common practice in the study area and this finding is in conformity with the observations of Singh et al. (2010).

The 'Adi' tribe community has their own indigenous knowledge system useful in conservation of natural resources. The trees which bear a distinct character or having unusual growth and shape are protected. They believe the presence of some unseen super natural power in such trees. They also worship the trees during their ritual ceremonies e.g. Taan (unidentified). They have developed their own system for harvesting different produces from the forest with least damage to the ecosystems. In case of fruits they never do the complete harvesting and leave some of the fruits on the trees. Young seedlings are also being protected from the animals by restricting the free grazing or by making fences during the specific period (natural regeneration). The respondents had shown their interest in cultivation/domestication of NWFPs providing species. The information was collected and ranking matrix was done in table 3 , which reveals the preference of species for domestication by Adi tribes. During the exercise different species/items were ranked on the basis of fixed scoring i.e. out of ten (Mukherjee, 2003). .Among different Non-Wood Forest Products providing species bamboo scored the first rank for its cultivation followed by tokopatta and rattan/cane, as 
these are the basic raw materials for construction of traditional tribal house. The other preferred species were katahal, onger, ongin, tapil, silum, hilika and amloki/amla.

Bamboo, tokopatta and rattan/cane are among the highly demanded non-wood forest products as they are used by the Adi community for various purposes. Bamboo, tokopatta and rattan/cane are chiefly used for the construction of their traditional houses. Young bamboo shoots are consumed as vegetable/pickle and also after fermentation; bamboo is used for making bamboo cup, bamboo baskets, bamboo tubes for storing Apong (local beer), rain shield (traditional umbrella made up of bamboo and tokopatta), bamboo spoons, bamboo mats, bows and arrows for hunting, etku (hunting trap for catching rat, squirrel, birds) etc. They also make different furniture and decorative items from bamboo and cane.

\section{Conclusion}

The present observation revealed that the Adi tribal community has a rich knowledge of Non-Wood Forest Products (NWFPs). They were using a number of NWFPs for their livelihood. These products played a significant role in supporting their livelihood, as 56.67 $\%$ people were earning Rs. 3000 - 6000 per month from the sale of different NWFPs. They $(>80 \%)$ were having the opinion that availability of these products has decreased considerably and this trend will continue in future, also. Although, they are playing an important role in conservation of different NWFPs yielding species by domesticating them in their home gardens, but it is not sufficient as the demand of these products is increasing year after year. Hence, some scientific interventions are required for their conservation so that the availability of these products may be maintained on sustainable basic.

\section{ACKNOWLEDGEMENT}

The authors are extremely thankful to the Adi community and Headmen of the study area for sharing their valuable knowledge and cooperation extended during the survey work. Help received from Mrs. Y J Lego, a traditional healer of Pasighat, East Siang District, AP, is highly acknowledged. The authors thank the Dean, College of Horticulture and Forestry, Pasighat, Arunachal Pradesh for providing the basic facilities and Central Agricultural University, Imphal for financial support to conduct the present study.

\section{REFERENCES}

Barik, S.K., Pandey, H.N., Tiwari, B.K. and Singh, B. (2006). Sacred Groves of Meghalaya, A scientific and conservation perspective. Regional Centre National Afforestation and Eco-Development Board, NEHU, Shilong, pp. 1-20.

Das, T. and Das T.K. (2005). Inventorying plant biodiversity in home gardens: A case study in Barak Valley, Assam, North East India, Curr. Sci., 98: 155-163.
Dattagupta, S. and Gupta, A. (2014). Traditional processing of non-timber forest products in Cachar, Assam, India. Indian Journal of Traditional Knowledge, 13 (2): $427-$ 433.

Desha M., Nagarajan B., and Jesubalan D. (2012). Future prospects for the critically endangered medicinally important species, Canarium strictum Roxb. - a review, International Journal of Conservation Science, 3 (3): 231-237.

FAO (1998). Forestry for food security. FAO Forestry Paper 90, Rome, Italy.

Kumar, N., Kumar, S., Singh, B. and Sen, D. (2011). Effect of pre-sowing treatments on seed germination of Gymnocladus burmanicus Parkinson, Environment and Ecology, 29 (1): 89-91.

Mao, A.A. and Hynniewta, T.M. (2000). Floristic diversity of North East India. J. Assam Sci. Soc., 41 (4): 255266. Mukherjee, N. (2003). Participatory Rural Appraisal - Methodology and Applications. Concept Publishing Company, New Delhi.

Muraleedharan, P.K., Sreelakshmi. K. and Anitha, V. (2004). Marketing, livelihood issues and depletion of NonWood Forest Products in Kerala. Journal of NonTimber Forest Products, 11 (4): 241-246.

Myers, N., Mittermeier, C.G., Fonseca, G.A.B. da., and Kent, J. (2001). Biodiversity hot spots for conservation priorities. Nature, 403: 853-858.

Narendran, K., Murthy, I. K., Suresh, H.S., Dattaraja, H.S., Ravindranath, N.H. and Sukumar, R. (2001). Nontimber forest product extraction, utilization and valuation: A case study from the Nilgiri Biosphere reserve, Southern India. Economic Botany, 55(4): 528-538.

Nayar, M.P. (1996). Hot Spots of Endemic Plants of India Nepal and Bhutan, SB Press Trivendrum.Pattanaik, C. and Reddy, S. C. (2012). Cyathea nilgirensis Holttum: a little known endemic species on the verge of extinction in Eastern Ghats, National Academy Science Letters, 35 (1): $17-18$.

Rao, R.R. and Hajra, P.K. (1980). Fern allies and ferns of Kameng District of Arunachal Pradesh, Indian Fort. Reco. Bot., 106: 327-349.

Samati, H. and Gogoi, R. (2007). Sacred Groves in Meghalaya. Curr. Sci., 93(10): 1338-1339.

Singh, R.K., Srivastava, R.C., Adi Community, and Mukherjee, T.K. (2010). Toko-Patta (Livistona jenkinsiana Griff.) : Adi community and conservation of culturally important endangered tree species in eastern Himalaya. Indian Journal of Traditional Knowledge, 9(2): 231241.

Singh, R.K., Sureja, A.K. and Turner, N.J. (2007). Food and cultural values of hidden harvest in livelihood of Adi tribes of Arunachal Pradesh. Indian Journal of Extension Education, 43(1\&2): 56-62.

Srivastava, R.C. and Adi Community (2009). Traditional knowledge of Adi tribe of Arunachal Pradesh on plants. Indian Journal of Traditional Knowledge, 8(2): 146153.

Srivastava , R.C. and Nyishi Community (2010). Traditional knowledge of Nyishi (Daffla) tribe of Arunachal Pradesh, Indian Journal of Traditional Knowledge, 9 (1) : 26-37.

Tangjang, S. and Arunachalam, A. (2009). Role of home garden systems in Northeast India, Indian Journal of Traditional Knowledge, 8 (1) : 47-50.

Tiwari, B.K., Barik, S.K. and Tripathi, R.S. (1999). Sacred 
Forests of Meghalaya, Biological and Cultural Diversity. Regional Centre National Afforestation and Eco-Development Board, NEHU, Shilong, pp. 1-120. Yumnam, J.Y., Bhuyan, S.I., Khan, M.L. and Tripathi, O.P. (2011). Agro-diversity of East Siang - Arunachal Pradesh,
Eastern Himalaya. Asian J. Agric. Sci., 3(4): 417-426. Yumnam, J.Y. and Tripathi, O.P. (2013). Ethnobotany: Plants use in fishing and hunting by Adi tribes of Arunachal Pradesh. Indian Journal of Traditional Knowledge, 12(1): 157-161. 